\title{
IL-18 and IL-12 induce intestinal inflammation and fatty liver in mice in an IFN- $\gamma$ dependent
} manner

S Chikano, K Sawada, T Shimoyama, S-I Kashiwamura, A Sugihara, K Sekikawa, $\mathrm{N}$ Terada, K Nakanishi, H Okamura Internal Medicine, Hyogo College of Medicine, Nishinomiya, Hyogo, 663-8501 Japan

S Chikano

K Sawada

T Shimoyama

Laboratory of Host Defenses, Institute for Advanced Medical Sciences, Hyogo

College of Medicine, Nishinomiya, Hyogo, 663-8501 Japan

S-I Kashiwamura K Nakanishi

H Okamura

First Department of Pathology, Hyogo College of Medicine, Nishinomiya, Hyogo, 663-8501 Japan A Sugihara

N Terada

Department of Immunology and Medical Zoology, Hyogo College of Medicine,

Nishinomiya, Hyogo, 663-8501 Japan

K Nakanishi

Department of Immunology, National Institute of Animal Health, Tsukuba City, Japan

K Sekikawa

Correspondence to: Dr S Chikano, Department Hyogo College of Medicine, 1-1, Mukogawa-cho, Nishinomiya, Hyogo, 663-8501 Japan.

Accepted for publication
Fourth Department of of Internal Medicine 4,

chikano-gi@umin.ac.jp 22 June 2000 KO mice, or MRL lpr/lpr mice lacking functional Fas were equally susceptible to IL-12 and IL-18. Administration of IL-12 and IL-18 did not induce TNF- $\alpha$ production in wild-type mice, and the same treatment to TNF- $\alpha$ KO mice induced intestinal mucosal inflammation. Furthermore, they had diffuse and dense infiltration of small fat droplets in their hepatocytes associated with an increase in serum levels of liver enzymes. In contrast, the same treatment in IFN- $\gamma$ KO BALB/c mice and iNOS KO mice did not induce these changes. Conclusions-Our study strongly indicates that IL-18 together with IL-12 induces intestinal mucosal inflammation in an IFN- $\gamma$ dependent but TNF- $\alpha$, NO, and Fas ligand independent manner, and fatty liver is dependent on IFN- $\gamma$ and NO. (Gut 2000;47:779-786)

Keywords: interleukins; interferon $\gamma$; intestinal inflammation; fatty liver; mice

$\mathrm{CD}^{+}{ }^{+} \mathrm{T}$ helper cells can be divided into $\mathrm{Th} 1$ and Th2 cells on the basis of their cytokine production profile. ${ }^{1}$ Their development de-

pends on the mode of priming: interleukin (IL)-12 and IL-4 induce differentiation of naive $T$ cells towards $T h 1$ or Th2 cells, respectively. $^{23}$ Macrophages are an essential immunological component of host defences and induce development of Th1 cells by production of IL-12, ${ }^{24-9}$ but also have the potential to induce host injury by production of proinflammatory cytokines..$^{2-9}$ IL-1 and tumour necrosis factor $\alpha$ (TNF- $\alpha)$, products of activated macrophages, induce lethal shock and evoke serious multiple organ failures when injected intravenously or tissue injury when locally injected..$^{7-9}$ IL-18, originally called interferon $\gamma(\mathrm{IFN}-\gamma)$ inducing factor, is a cytokine of $18 \mathrm{kDa}$ synthesised by Kupffer cells and activated macrophages. ${ }^{4} 10^{11}$ Although IL-18 cannot induce Th1 cell development, ${ }^{12}{ }^{13}$ this 

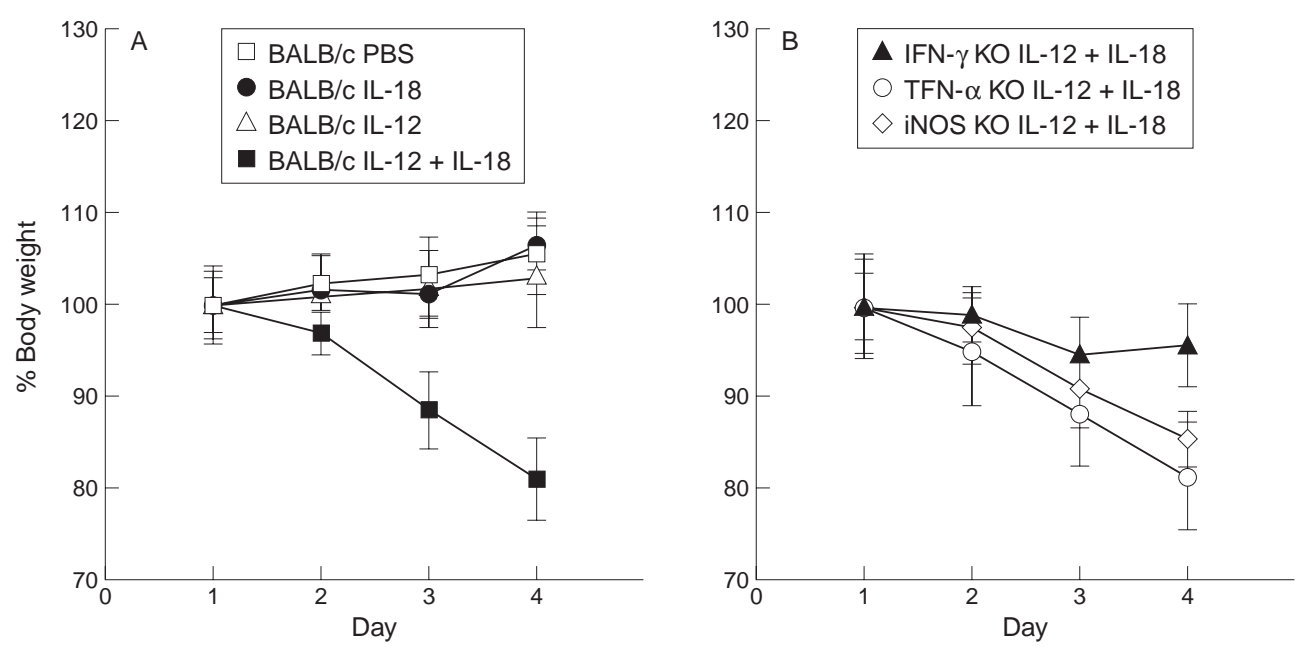

Figure 1 (A) Relative body weight of $B A L B / c$ and IFN- $\gamma K O$ mice injected with each reagent. Weights of $B A L B / c$ mice injected with PBS (200 $\mu \mathrm{l})$ ), IL-18 (200 ng/g/mouse), IL-12 (20 ng/g/mouse), IL-12 (20 ng/g/mouse) plus IL-18 (200 $\mathrm{ng} / \mathrm{g} / \mathrm{mouse}$ ) are shown. Each group consists of five mice. The weight of $B A L B / \mathrm{c} \mathrm{mice} \mathrm{injected} \mathrm{with} \mathrm{IL-12} \mathrm{(20} \mathrm{ng/g/mouse)}$ together with IL-18 (200 ng/g/mouse) on day 4 was $82.0 \%$ of that of the first day and this weight loss was significant ( $p$ <0.01). (B) Relative body weight of IFN- $\gamma \mathrm{KO}, \mathrm{TNF}-\alpha \mathrm{KO}$, and $i N O S \mathrm{KO}$ mice injected with IL-12 (20 ng/g/mouse) plus IL-18 (200 ng/g/mouse). Each group consists of five mice. The weight of IFN- $\gamma$ KO mice given the same treatment on day 4 was $95.2 \%$ of that of the first day and weight loss was not significant. Weight loss in the other two groups was significant. Each group of mice injected with PBS (200 $\mu \mathrm{l}$ ) daily showed no pathological findings and no weight loss (data not shown).

most of which show evidence of aberrant Th1 responses. ${ }^{21-26}$ In these models, colonic inflammation is considered to be caused by a dysregulated Th1 response but some are caused by alteration of the balance between the effects of IFN- $\gamma$ and transforming growth factor $\beta .^{26-28} \mathrm{Th}-2$ mediated colitis has also been reported. ${ }^{29}{ }^{30}$ More recently, it has been demonstrated that the development of pathogenic $\mathrm{T}$ cells is influenced predominantly by IL-12 via the action of signal transducer and activator of transcription-4 proteins, and IFN- $\gamma$ is required to establish colitis. ${ }^{31}$ But it has also been demonstrated that other inflammatory mediators are sufficient to mediate disease. ${ }^{31}$ To determine the pathological role of IL-12 and IL-18 in vivo, we investigated if adminis-

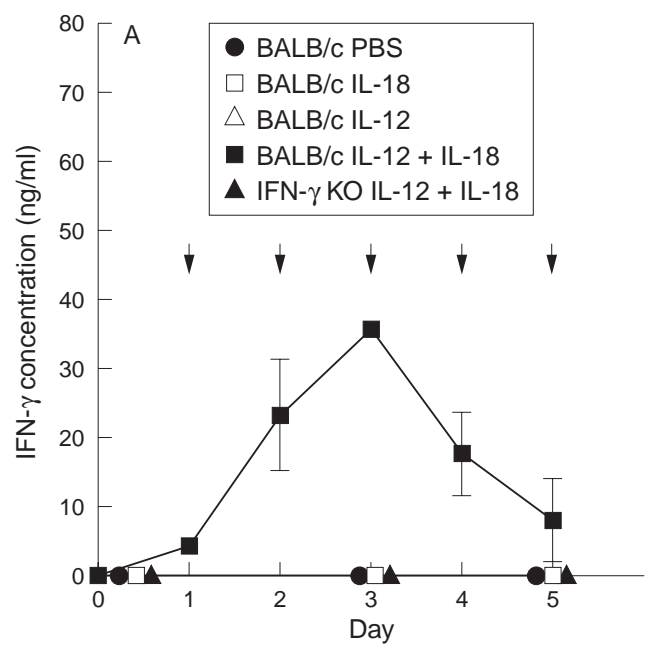

tration of IL-12 and IL-18 induces IFN- $\gamma$ production that may promote mucosal inflammation and liver injury with hepatitis. We also investigated if other inflammatory factors, such as TNF- $\alpha$ and nitric oxide (NO), are involved in mucosal inflammation and if IFN- $\gamma$ knockout $(\mathrm{KO})$ mice are resistant to this treatment.

\section{Materials and methods}

MICE

Specific pathogen free BALB/c mice, designated BALB/c-wild-type (wt), and MRL lpr/lpr mice (female, 7-8 weeks of age) were obtained from Shizuoka Laboratory Animal Centre (Shizuoka, Japan). IFN- $\gamma$ KO mice mere $^{32}$ wents backcrossed to BALB/c mice for F8 generations, and the resultant female BALB/c-IFN- $\gamma$

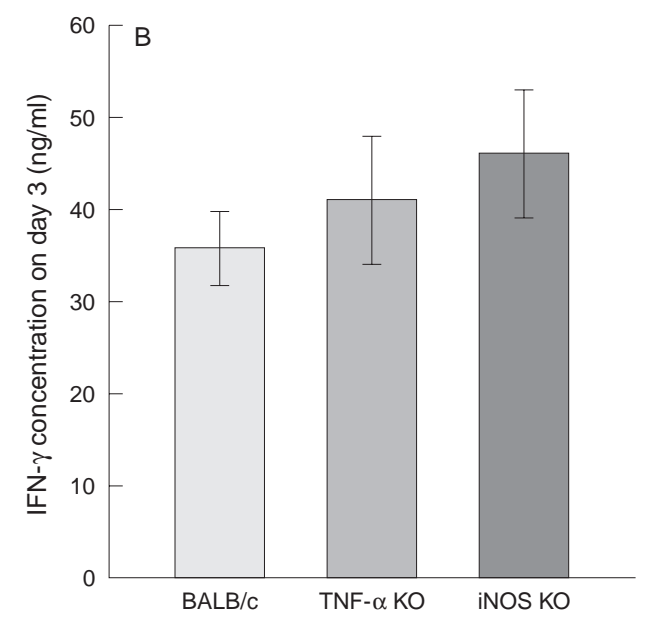

Figure 2 (A) IFN- $\gamma$ concentrations in the serum of BALB/c mice injected with IL-12 (20 ng/g/mouse) plus IL-18 (200 ng/g/mouse), IL-12 (20 ng/g/mouse), IL-18 (200 $\mathrm{ng} / \mathrm{g} /$ mouse), or PBS (200 $\mu \mathrm{l}$ ) in addition to IFN- $\gamma$ KO mice given the same treatment. Each group consists of five mice. Samples were collected six hours after injection every day. IFN- $\gamma$ production was observed only in the serum of $B A L B / c$ mice injected with IL-12 plus IL-18; it increased daily until day 4 and then decreased on day 5. Arrows show injection of IL-12 plus IL-18. (B) IFN- $\gamma$ concentrations in the serum of $B A L B / c, T N F-\alpha \mathrm{KO}$, and $i N O S \mathrm{KO}$ mice injected with IL-12 (20 ng/g/mouse) plus IL-18 (200 ng/g/mouse) daily. Each group consists of five mice. Samples were collected six hours after injection on day 3. High levels of IFN- $\gamma$ production were observed in the serum of TNF- $\alpha$ KO and $i N O S K O$ mice, and were higher than those of BALB/c mice. 
$\mathrm{KO}$ mice at 6-8 weeks old were used in this study. Inducible nitric oxide synthase knock out (iNOS $\mathrm{KO}$ ) mice with $\mathrm{C} 57 \mathrm{BL} / 6$ background (female, 7-8 weeks old) were obtained from Jackson Laboratory (Bar Harbor, Maine, USA). TNF- $\alpha \mathrm{KO}$ mice were produced as described previously. ${ }^{32}$

REAGENTS AND ANTIBODY

Recombinant mouse IL-12 and IL-18 were produced and prepared as described previously. ${ }^{43}$

IN VIVO TREATMENT OF MICE

Mice (BALB/c-wt, MRL-lpr/lpr, BALB/cIFN- $\gamma \mathrm{KO}, \mathrm{C} 57 \mathrm{BL} / 6-\mathrm{iNOS} \mathrm{KO}, \mathrm{BALB} / \mathrm{c}-$ TNF- $\alpha \mathrm{KO}$, each group $\mathrm{n}=5$ ) were injected intraperitoneally each day with $20 \mathrm{ng} / \mathrm{g} /$ mouse of IL-12 and/or $200 \mathrm{ng} / \mathrm{g} / \mathrm{mouse}$ of IL-18 in $200 \mu \mathrm{l}$ of phosphate buffered saline (PBS). Control mice were injected intraperitoneally each day with $200 \mu$ of PBS alone. Mice were weighed daily and monitored for appearance and signs of illness, such as loose stools, diarrhoea, and physical activity. Mice were sacrificed on day 5 after injection and their organs were examined after fixation. Before sacrifice, sera were sampled, aliquoted, and frozen at $-20^{\circ} \mathrm{C}$ until measurement of alanine transaminase (ALT), cytokines, and NO levels. Serum levels of liver enzyme, cytokines, and $\mathrm{NO}$ are presented as mean (SEM) values of five mice.

HISTOLOGICAL ANALYSIS

Liver specimens were sampled on day 5 at the indicated times after the last injection of IL-12 and/or IL-18 and fixed in 3.5\% formaldehyde in PBS. Sections $(2 \mu \mathrm{m})$ were cut and placed on slides for staining with haematoxylin and eosin using a standard technique. Hepatocytes were also examined for the presence of lipid by staining with oil red O. Specimens were fixed in

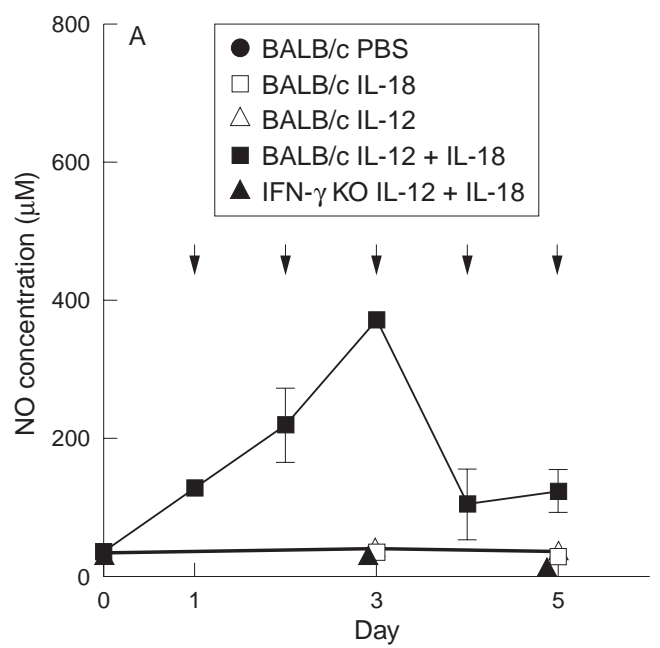

Figure 3 (A) NO concentrations in the serum of BALB/c mice injected with PBS (200 $\mu \mathrm{l}), \mathrm{IL}-18$ (200 ng/g/mouse), IL-12 (20 ng/g/mouse), IL-12 (20 ng/g/mouse) plus IL-18 (200 ng/g/mouse), and IFN- $\gamma$ KO mice injected with IL-12 (20 ng/g/mouse) plus IL-18 (200 ng/g/mouse). Each group consists of five mice. Samples were collected six hours after injection. Prominent production of NO is observed only in the serum of BALB/c mice injected with IL-12 plus IL-18. It appears that NO production was elevated and decreased in parallel with IFN- $\gamma$ production in $B A L B / c$ mice treated with $I L-12$ plus IL-18. Arrows show injections of $I L-12$ plus IL-18. (B) NO concentrations in the serum of $B A L B / c, T N F-a$ $\mathrm{KO}$, and $\mathrm{N} N \mathrm{SO}$ KO mice injected with IL-12 (20 ng/g/mouse) plus IL-18 (200 $\mathrm{ng} / \mathrm{g} /$ mouse) daily. Each group consists of five mice. Samples were collected six hours after injection on day 3. High levels of NO production were observed in the serum of $B A L B / c$ and TNF-a KO mice. Low levels of NO production were observed in iNOS KO mice.

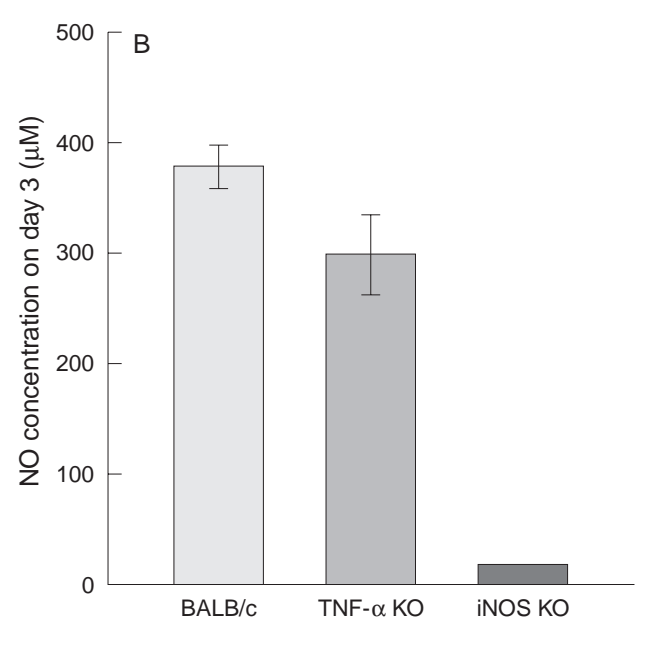

$10 \%$ neutral buffered formalin. After fixation, they were frozen at $-20^{\circ} \mathrm{C}$, sliced $(2-4 \mu \mathrm{m})$, and stained with oil red $\mathrm{O}$. Colon tissues were solution and embedded in paraffin. Sec( $\mu \mathrm{m})$ were cut and placed on slides and histological scoring of liver injury, 10 fields were evaluated at $\times 40$ magnification.

For electron microscopy, the liver was perfused via the portal vein with saline for 20 seconds, and then with the prefixative contain$1.5 \%$ glutaraldehyde, $0.067 \mathrm{M}$ cacodylate buffer ( $\mathrm{pH} 7.4)$, and $1 \%$ sucrose $(310 \mathrm{mosmol})$ for $1-2$ minutes at a flow rate of $10 \mathrm{ml} / \mathrm{min}$ at romperature. Tissue blocks from the liver (pH 7.4) at $4^{\circ} \mathrm{C}$ for two hours, further minutes at room temperature, dehydrated in tranol series, and embedded in Epon. Uluranyl acetate and lead citrate, and observed under a JEOL $100 \mathrm{C} \times$ electron microscope at ELISA

Serum concentration of IFN- $\gamma$ and TNF- $\alpha$ were determined using ELISA kits (Genzyme, NO ASSAY

Serum levels of NO were measured using Griess reagent (Dojin, Chm. Lab. Institute, STATISTICAL ANALYSIS

The paired two tailed Student's $t$ test was performed for statistical analysis. Probabilities of $5 \%$ or less were considered statistically significant. processed with $2 \%$ uranyl acetate for 20 

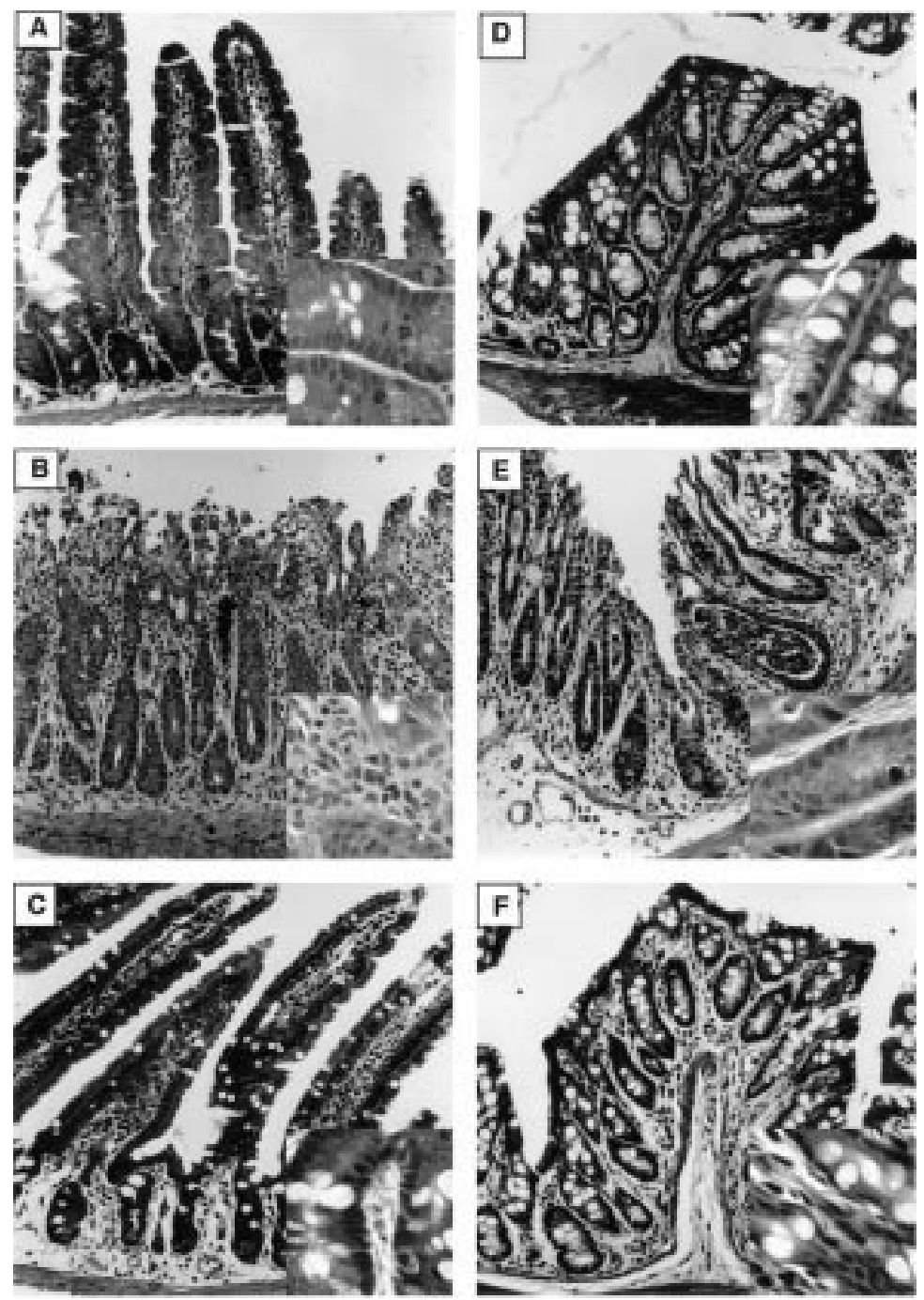

Figure 4 Histology of the jejunum $(A-C)$; haematoxylin-eosin $\times 350$. (A) Fejunum of $B A L B / c$ mouse injected with PBS. (B) fejunum of $B A L B / c$ mouse injected with both $I L-12$ (20 ng/g/mouse) and IL-18 (200 ng/g/mouse). (C) Fejunum of IFN- $\gamma$ KO mouse injected with both IL-12 (20 $\mathrm{ng} / \mathrm{g} / \mathrm{mouse}$ ) and IL-18 (200 $\mathrm{ng} / \mathrm{g} / \mathrm{mouse})$. Histology of the colon $(D-F)$; haematoxylin-eosin $\times 350$. (D) Colon of $B A L B / c$ mouse injected with $P B S$. (E) Colon of $B A L B / c$ mouse injected with both IL-12 (20 ng/g/mouse) and IL-18 (200 $\mathrm{ng} / \mathrm{g} / \mathrm{mouse}$ ). (F) Colon of IFN- $\gamma \mathrm{KO}$ mouse injected with both IL-12 (20 ng/g/mouse) and $I L-18$ (200 $\mathrm{ng} / \mathrm{g} / \mathrm{mouse}$ ).

\section{Results}

IL-12 AND IL-18 INDUCE WEIGHT LOSS IN AN IFN- $\gamma$ DEPENDENT MANNER

We first tested if injection of IL-12 and/or IL-18 induced weight loss in an IFN- $\gamma$ dependent manner. For this purpose, we examined the effect of IL-12 and/or IL-18 on the gross clinical symptoms of $\mathrm{BALB} / \mathrm{c}-w \mathrm{t}$, TNF- $\alpha \mathrm{KO}$, iNOS KO, and IFN- $\gamma \mathrm{KO}$ mice. $\mathrm{BALB} / \mathrm{c}-\mathrm{wt}$ mice injected daily with IL-12 (20 $\mathrm{ng} / \mathrm{g} / \mathrm{mouse}$ ) or IL-18 (200 ng/g/mouse) retained a healthy appearance during monitoring. In contrast, $\mathrm{BALB} / \mathrm{c}-\mathrm{wt}, \mathrm{TNF}-\alpha \mathrm{KO}$, and iNOS KO mice injected daily with a mixture of IL-12 and IL-18 showed weight loss and overt clinical symptoms, such as piloerection and in most cases diarrhoea which was occasionally accompanied by visible blood. Furthermore, these symptoms advanced progressively, and eventually almost all mice died by day 6 . Interestingly, the same treatment to BALB/c-IFN- $\gamma$ $\mathrm{KO}$ mice caused only slight weight loss. Weight loss of wild-type mice injected with IL-12 and IL-18 was clearly illustrated (fig $1 \mathrm{~A}$ ), and TNF- $\alpha \mathrm{KO}$ and iNOS KO mice given the same treatment also showed a marked decrease in weight (fig 1B). However, IFN- $\gamma \mathrm{KO}$ mice given the same treatment showed a moderate decrease in weight (fig 1B). TNF- $\alpha \mathrm{KO}$, iNOS $\mathrm{KO}$, and IFN- $\gamma \mathrm{KO}$ mice injected with PBS showed no clinical symptoms or weight loss (data not shown). This decrease in weight in wild-type, TNF- $\alpha \mathrm{KO}$, and iNOS KO mice but not in IFN- $\gamma$ KO mice after injection of IL-12 and IL-18 was significant $(\mathrm{p}<0.01)$.

We next examined the capacity of IL-12 and IL-18 to induce IFN- $\gamma$ production in wild-type, $\mathrm{TNF}-\alpha \mathrm{KO}$, and iNOS $\mathrm{KO}$ mice. As shown in fig $2 \mathrm{~A}$, wild-type mice showed markedly increased levels of IFN- $\gamma$ in sera. Kinetic studies revealed that levels of IFN- $\gamma$ were highest on day $3(35.10(0.05) \mathrm{ng} / \mathrm{ml})$ after the start of daily injections of a mixture of IL-12 and IL-18. But these levels declined thereafter and became very low on days 4 and 5 . TNF- $\alpha \mathrm{KO}$ and iNOS $\mathrm{KO}$ mice also showed increased levels of IFN- $\gamma$ on day 3 (fig 2B). Levels of NO correlated well with those of IFN- $\gamma$ in wild-type mice injected with IL-1 2 and IL-18 (fig 3A). In TNF- $\alpha$ KO mice, IFN- $\gamma$ produced by stimulation with IL-12 and IL-18 also showed high levels of $\mathrm{NO}$ on day 3 (fig 3B). Furthermore, IFN- $\gamma$ KO mice showed no such increase in serum levels of $\mathrm{NO}$ after IL-12 and IL-18 treatment (fig 3A), suggesting that IL-12 and IL-18 synergistically induce IFN $-\gamma$ production that stimulates macrophages and other types of cells to produce NO. However, IFN- $\gamma$ induced NO production was not pathogenic because reagents such as aminoguanidine that prevent iNOS dependent NO production failed to protect $\mathrm{BALB} / \mathrm{c}-\mathrm{wt}$ mice from IL-12 and IL-18 induced weight loss (data not shown). Moreover, iNOS KO mice were equally susceptible to IL-12 and IL-18 in the intestines (fig 5C, F). However, in the liver of iNOS KO mice injected with IL-12 and IL-18, the pathological changes and elevation of ALT were less than those of wild-type and TNF- $\alpha$ $\mathrm{KO}$ mice (figs $6 \mathrm{E}, 7$ ). TNF- $\alpha$ was not elevated in the sera of mice injected daily with IL-12 and IL-18 (data not shown). TNF- $\alpha \mathrm{KO}$ mice given the same treatment manifested weight loss (fig 1B) accompanied by intestinal inflammation (fig 5B, E). MRL lpr/lpr mice were also susceptible to treatment with IL-12 and IL-18, with weight loss accompanied by intestinal inflammation (fig 5A, D). Thus IL-12 and IL-18 induced weight loss and intestinal inflammation in an IFN- $\gamma$ dependent but TNF- $\alpha$, NO, and Fas $\mathrm{L} / \mathrm{Fas}$ independent manner.

HISTOPATHOLOGY OF SMALL AND LARGE INTESTINES IN MICE INJECTED WITH IL-12 AND IL-18

Next, requirement for IFN- $\gamma$ for induction of these clinical symptoms was tested by comparing pathological changes in wild-type and IFN- $\gamma$ KO mice after treatment with IL-12 and IL-18 (figs 4, 6). As inferred from the severe diarrhoea seen in wild-type mice injected with IL-12 and IL-18, the small intestine, especially the jejunum, was severely damaged. There 

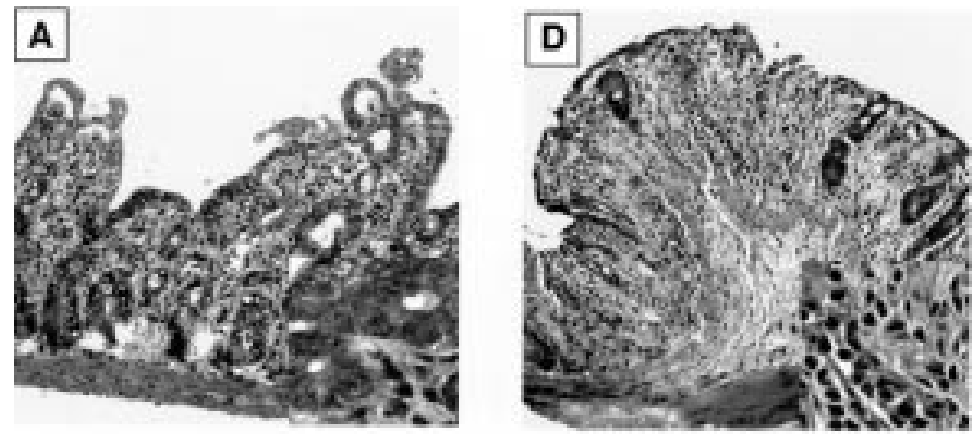

B
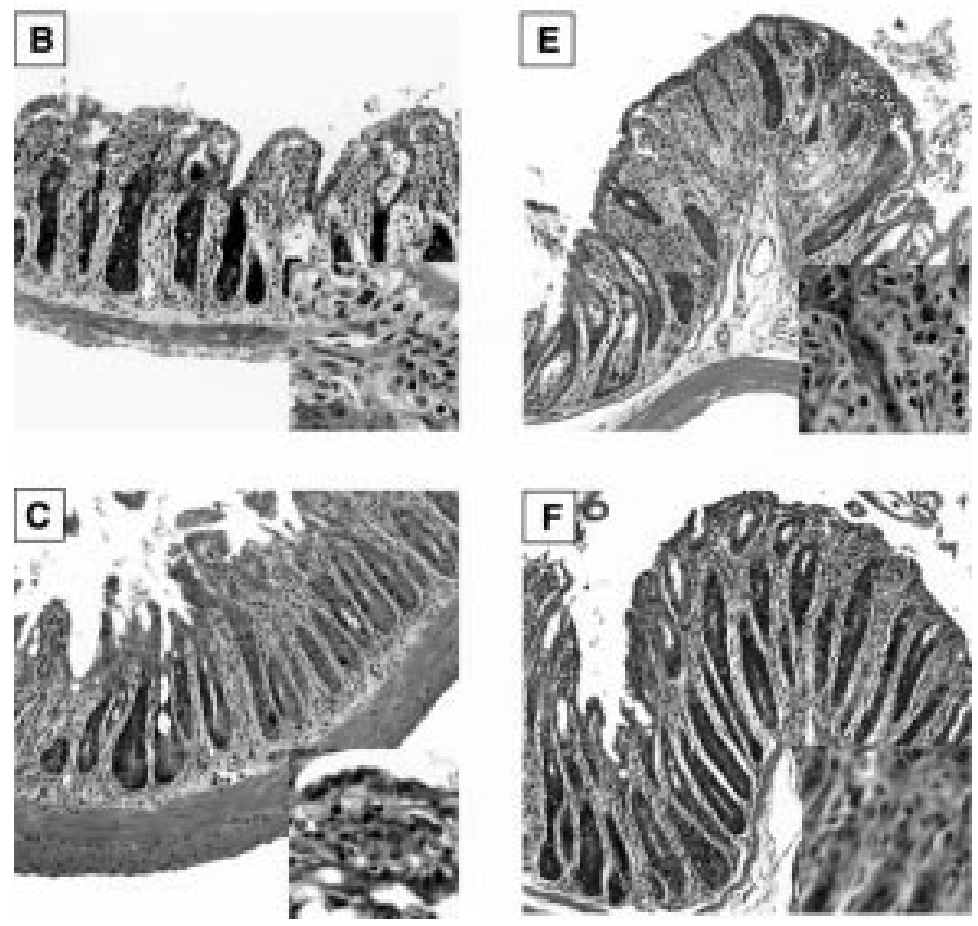

Figure 5 Histology of the jejunum $(A-C)$; haematoxylin-eosin $\times 350$. (A) fejunum of MRL lpr/lpr mouse injected with both IL-12 (20 ng/g/mouse) and IL-18 (200 $\mathrm{ng} / \mathrm{g} /$ mouse). (B) Fejunum of TNF-aKO mouse injected with both IL-12 (20 ng/g/mouse) and IL-18 (200 ng/g/mouse). (C) Fejunum of iNOS KO mouse injected with both IL-12 (20 ng/g/mouse) and IL-18 (200 $\mathrm{ng} / \mathrm{g} / \mathrm{mouse})$. In all of these jejunums, a decrease in the height of the villi and infiltration of inflammatory cells were observed. Histology of the colon $(D-F)$; haematoxylin-eosin $\times 350$. (D) Colon of MRL lpr/lpr mouse injected with both IL-12 (20 ng/g/mouse) and IL-18 (200 ng/g/mouse). (E) Colon of TNF- $\alpha$ KO mouse injected with both IL-12 (20 ng/g/mouse) and IL-18 (200 ng/g/mouse). (F) Colon of $i$ NOS KO mouse injected with both IL-12 (20 ng/g/mouse) and IL-18 (200 ng/g/mouse). In all of these colons, a decrease in the number of goblet cells was observed. Prominent infiltration of the inflammatory cells was observed in the colon of the MRL lpr/lpr mouse.

were erosions with shortened villi, elongated crypts, and diminished number of goblet cells and Paneth cells in crypts (fig 4B), while IFN- $\gamma$ $\mathrm{KO}$ mice were free of these pathological changes (fig 4C). Additional common histological findings in the crypts of the small intestine obtained from wild-type mice treated with IL-12 and IL-1 8 were increases in the numbers of mitotic and apoptotic cells (data not shown). We also observed diffuse infiltration of inflammatory cells, including lymphocytes, plasma cells, and neutrophils in the mucosa. Similar changes were also observed in the small intestines of MRL lpr/lpr (fig 5A), TNF- $\alpha \mathrm{KO}$ (fig 5B), and iNOS $\mathrm{KO}$ mice (fig 5C) when they were injected with IL-12 and IL-18. In contrast, IFN- $\gamma$ KO mice given the same treatment did not show these changes (fig 4C) suggesting that IL-12 and IL-18 induce mucosal inflammation in an IFN- $\gamma$ dependent but TNF- $\alpha, \mathrm{NO}$, and Fas L/Fas independent manner.

Treatment of wild-type mice with IL-12 and IL-18 also induced marked colonic mucosal inflammation whereas the same treatment of IFN- $\gamma$ KO mice did not. Histological study revealed the presence of elongated crypts and multiple mucosal erosions (fig $4 \mathrm{E}$ ). Again, induction of these pathological changes depended on the synergistic action of IL-12 and IL-18. Neither IL-12 nor IL-18 induced such changes (data not shown). The crypts were characterised by an increase in the number of mitotic as well as apoptotic cells. Furthermore, a marked decrease in the number of goblet cells was often observed, presumably leading to mucin depletion. The number of inflammatory cells, including lymphocytes, plasma cells, and neutrophils, increased in the mucosa, and crypt abscesses were also found (fig $4 \mathrm{E}$ ). In contrast with wild-type mice treated with IL-12 and IL-18, IFN- $\gamma \mathrm{KO}$ mice were resistant to the action of IL-12 and IL-18 in inducing mucosal inflammation in the colon (fig 4F). Microscopic changes were also observed in the colons of TNF- $\alpha$ KO, MRL lpr/lpr, and iNOS KO mice treated with IL-12 and IL-18 (fig 5D-F).

HISTOPATHOLOGY OF THE LIVER IN MICE

INJECTED WITH IL-12 AND IL-18

Treatment of $P$ acnes primed mice with LPS induces severe liver injury. ${ }^{4618}$ Anti-IL-12 antibody and/or anti-IL-18 antibody blocked liver injury induced by $P$ acnes and LPS, ${ }^{18} 20$ indicating that IL-12 and IL-18 play critical roles in the pathogenesis of LPS induced liver injury. Therefore, we investigated the capacity of IL-12 and IL-18 to induce liver injury in $\mathrm{BALB} / \mathrm{c}-\mathrm{wt}$ mice. We also tested the requirement for IFN- $\gamma$ in induction of liver injury by using $\mathrm{BALB} / \mathrm{c}$ IFN- $\gamma \mathrm{KO}$ mice. We administered IL-12 and/or IL-18 daily to BALB/c-wt and IFN- $\gamma \mathrm{KO}$ mice for four days and examined pathological changes in their livers.

Two hours after the last injection of IL-12 and/or IL-18, mice were sacrificed for histological analysis. In the liver of BALB/c-wt mice injected with IL-12 and IL-18 for four days, hepatocytes were enlarged, and most dramatically, their cytoplasm was occupied by multiple small vacuoles which surrounded a central nucleus (fig 6B). In addition, apoptotic cells containing condensed and unevenly distributed chromatins were sporadically found among these hepatocytes (fig 6B). In contrast with the histology of the liver of $P$ acnes primed and LPS challenged mice, ${ }^{18} 20$ infiltration of mononuclear cells was limited and only a small number of mononuclear cells were observed in the lobes. Staining frozen sections with oil red O showed positive stain of these vacuoles (data not shown), indicating that these droplets were lipid. Hepatocytes were also examined with an electron microscope. Figure $6 \mathrm{G}$ shows an electron micrograph of an apoptotic cell in the liver of BALB/c-wt mice administered IL-12 and IL-18 for four days. An apoptotic cell detached from neighboring cells and the cytoplasm condensed, reserving cellular integrity was ob- 

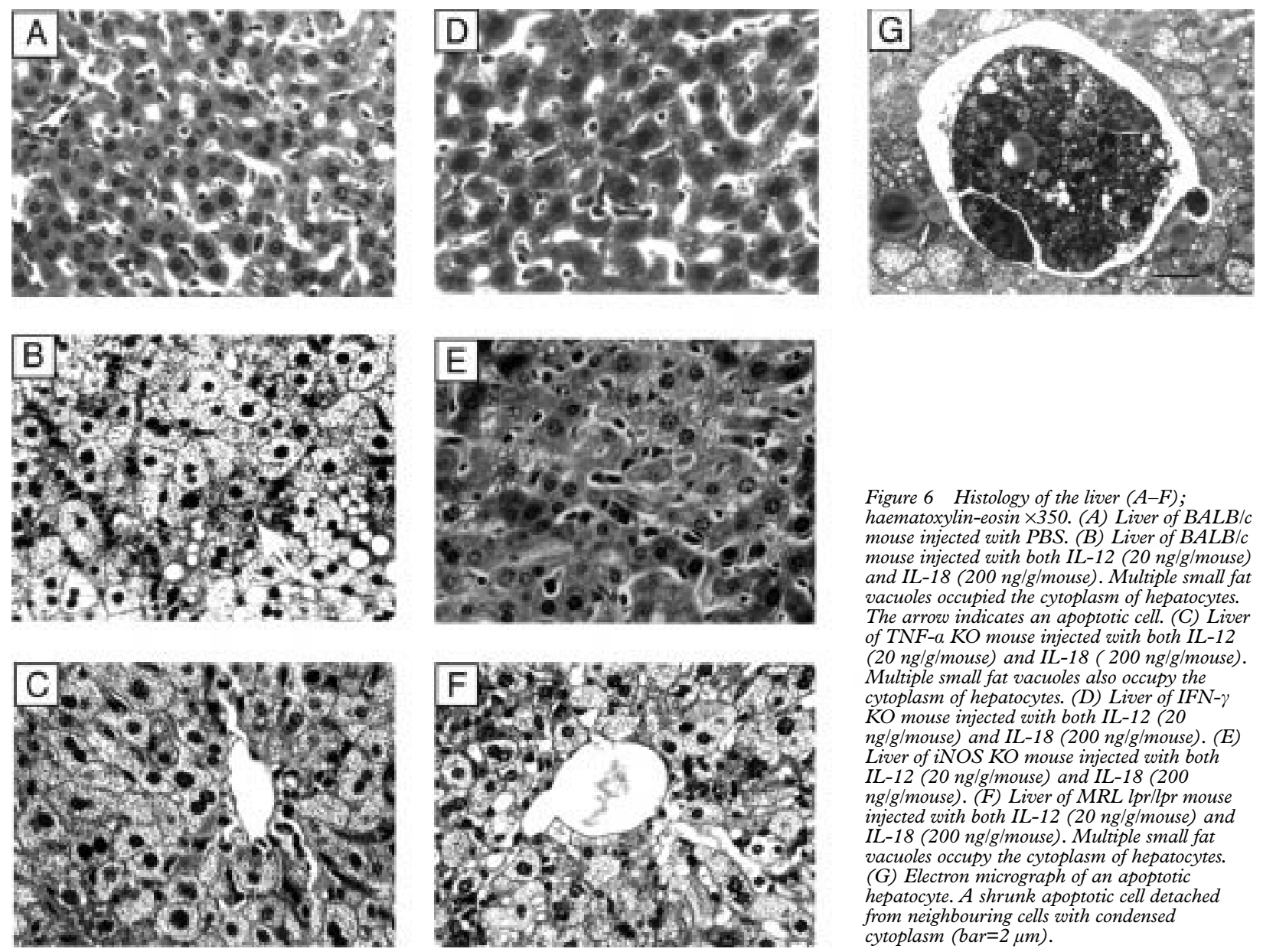

Figure 6 Histology of the liver $(A-F)$,

haematoxylin-eosin $\times 350$. (A) Liver of $B A L B / c$ mouse injected with $P B S$. (B) Liver of $B A L B / c$ mouse injected with both IL-12 (20 ng/g/mouse) and IL-18 (200 $\mathrm{ng} / \mathrm{g} /$ mouse). Multiple small fat vacuoles occupied the cytoplasm of hepatocytes. The arrow indicates an apoptotic cell. $(C)$ Liver of TNF-a KO mouse injected with both IL-12 (20 ng/g/mouse) and IL-18 (200 ng/g/mouse). Multiple small fat vacuoles also occupy the cytoplasm of hepatocytes. (D) Liver of IFN- $\gamma$ KO mouse injected with both IL-12 (20 $\mathrm{ng} / \mathrm{g} / \mathrm{mouse})$ and $I L-18$ (200 ng/g/mouse). (E) Liver of $i N O S \mathrm{KO}$ mouse injected with both IL-12 (20 ng/g/mouse) and IL-18 (200 $n g / g /$ mouse). (F) Liver of MRL lpr/lpr mouse injected with both IL-12 (20 ng/g/mouse) and IL-18 (200 ng/g/mouse). Multiple small fat vacuoles occupy the cytoplasm of hepatocytes. (G) Electron micrograph of an apoptotic hepatocyte. A shrunk apoptotic cell detached from neighbouring cells with condensed cytoplasm (bar $=2 \mu \mathrm{m})$.

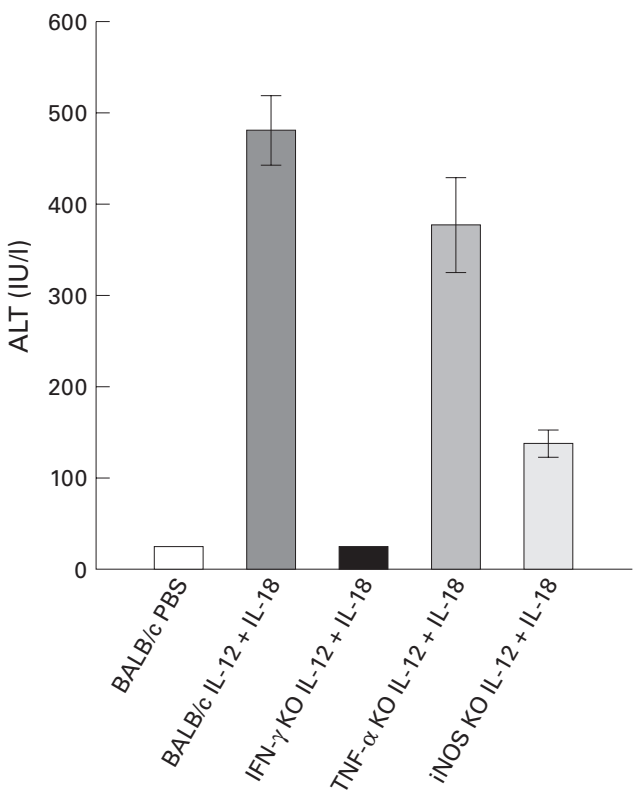

served. Furthermore, these mice showed increased levels of ALT in sera (fig 7). Similar pathological changes were observed in the livers of $\mathrm{TNF}-\alpha \mathrm{KO}$ mice (fig $6 \mathrm{C}$ ) who also showed increased levels of ALT in sera (fig 7). MRL lpr/lpr mice given the same treatment also showed fatty degeneration in the liver (fig $6 \mathrm{~F}$ ). The liver of iNOS $\mathrm{KO}$ mice injected with IL-12 and IL-18 did not show pathological fatty changes (fig $6 \mathrm{E}$ ). Also, increased levels of ALT were less than those of wild-type and TNF- $\alpha$ KO mice (fig 7). These findings indicate that NO has some role in inducing fatty degeneration of the liver. In contrast, IFN- $\gamma$ KO mice injected with IL-12 and IL-18 did not show pathological changes in their livers (fig 6D), and ALT levels in sera were almost the same as those in PBS injected mice (fig 7), indicating that IFN- $\gamma \mathrm{KO}$ mice were also resistant to the action of IL-12 and IL-18 in inducing fatty liver degeneration.

\section{Discussion}

We have shown that administration of a mixture of IL-18 and IL-12 to wild-type mice induced weight loss and intestinal inflamma-

Figure 7 Serum alanine transaminase (ALT) levels (mean (SEM)). ALT levels in the sera of $B A L B / c-w t$, $I F N-\gamma K O, T N F-\alpha K O$, and $i N O S K O$ mice (five mice), and in $B A L B / c$ wt injected with PBS (five mice). Samples were collected six hours after injection on day 5. Highly elevated levels of $A L T$ were observed in $B A L B / c$-wt and $T N F-a$ KO mice. Moderately elevated levels of $A L T$ were observed in iNOS KO mice and normal levels in IFN- $\gamma$ $K O$ mice treated with $I L-12$ and $I L-18$ and $B A L B / c$ wt mice treated with $P B S$. mice displayed marked histopathological changes such as erosions of the small intestines as well as fatty degeneration of the liver (fig $4 \mathrm{~B}$, $\mathrm{E}$; fig $6 \mathrm{~B}$ ). Induction of these changes required combined administration of IL-18 and IL-12. We previously reported a synergistic effect of 
IL-18 and IL-12 on IFN- $\gamma$ production by T cells. ${ }^{1111617}$ Our molecular analysis revealed that IL-12 rendered T cells responsive to IL-18 by induction of IL-18 receptor expression. ${ }^{17}$ Apart from this mechanism, IL-18 and IL-12 were shown to independently activate different transcription factors (nuclear factor $\mathrm{\kappa B}$ and activator protein 1 ), which in combination may synergistically activate the promoter site of the IFN- $\gamma$ gene. ${ }^{16}{ }^{34} 35$

IL-12 and IL-18 induced mucosal inflammation was characterised by the presence of villous atrophy, and loss of Paneth and goblet cells (fig $4 \mathrm{~B}, \mathrm{E}$ ). This inflammation was also associated with an increase in the numbers of apoptotic and mitotic cells (data not shown). Less frequent findings included erosions of mucosa. We also showed that injection of a mixture of IL-12 and IL-18 induced high levels of IFN- $\gamma$ production and mucosal inflammation with a fatty liver in wild-type but not IFN- $\gamma \mathrm{KO}$ mice, clearly indicating that IFN $-\gamma$ has an important role in the induction of these pathological changes. This is considered to be Th1 mediated colitis and IFN- $\gamma$ has an important role. However, injection of high doses of IFN- $\gamma(10 \mu \mathrm{g} /$ mouse $)$ failed to replace the action of IL-12 and IL-18 (data not shown), suggesting that IFN- $\gamma$ may require the presence of other factors induced by the action of IL-12 and IL-18 to have pathological effects.

In some forms of chronic experimental colitis, the development of pathogenic $\mathrm{T}$ cells is influenced by the IL-12/IFN- $\gamma$ pathway. ${ }^{31}$ Hence IL-12 alone may be able to induce colitis in mice. We injected IL-12 $(20 \mu \mathrm{g} / \mathrm{g} /$ mouse $)$ daily into mice but they did not show pathological changes; higher doses may be necessary. Recently, there have been some reports of Th2-mediated colitis ${ }^{29}{ }^{30}$ and IL-18 may potentiate the Th2 responses. ${ }^{36-38}$ Hence high doses of IL-18 may induce colitis in mice. We injected IL-18 $5 \mu \mathrm{g} / \mathrm{mouse}$ daily for five days and observed clinical changes but there were no pathological changes such as weight loss or diarrhoea (data not shown). In this study, we injected both IL-12 and IL-18 to induce colitis but this may not be an absolute requirement.

In this study, we found that in common with BALB/c-wt mice treated with IL-12 and IL-18, MRL-lpr/lpr mice lacking functional Fas due to mutation suffered weight loss with diarrhoea and manifested intestinal inflammation after treatment. This suggests that these pathological changes were induced in a Fas independent manner. Further studies are needed to elucidate factors other than IFN- $\gamma$ in inducing these pathological effects.

IFN- $\gamma$ has various effects on macrophages and other cell types, and induces $\mathrm{NO}$ and TNF- $\alpha$ production. ${ }^{39}$ As TNF- $\alpha$ contributes to local inflammatory reactions that are harmful to the host, we examined the possibility that IL-12 and IL-18 induce pathological changes via TNF- $\alpha$. However, TNF- $\alpha$ was not detected in sera obtained daily after initiation of injection of IL-12 and IL-18 by ELISA (data not shown). Furthermore, TNF- $\alpha \mathrm{KO}$ mice treated with IL-12 and IL-18 suffered weight loss (fig 1B) accompanied by intestinal inflammation (fig 5B, E) and fatty liver (fig 6C). Hence we conclude that TNF- $\alpha$ is not responsible for inducing this pathological state. It is well known that IFN- $\gamma$ induces TNF- $\alpha$ production. $^{40}$ Nevertheless, administration of IL-12 and IL-18 failed to induce TNF- $\alpha$, even if high levels of IFN- $\gamma$ were observed. It is intriguing to speculate that IL-18 is a negative regulator of $\mathrm{TNF}-\alpha$ production induced by IFN- $\gamma$.

IL-12 and IL-18 caused marked increases in serum levels of IFN- $\gamma$ and NO in BALB/c-wt mice (figs $2 \mathrm{~A}, 3 \mathrm{~A}$ ). On day 3 , peak increases in both occurred (figs 2A, 3A). NO production was IFN- $\gamma$ dependent because no such increase occurred in IFN- $\gamma$ KO mice treated with IL-12 and IL-18 (fig 3A). TNF- $\alpha$ was reported to induce NO production. ${ }^{41}$ However, as noted above, TNF- $\alpha$ was not detected in mice treated with IL-12 and IL-18 for unknown reasons, leading to no NO production in IFN- $\gamma \mathrm{KO}$ mice. Changes in serum levels of IFN- $\gamma$ were closely correlated with those of NO, in terms of both levels and time after stimulation with IL-12 and IL-18. There are at least two possibilities to account for this correlation. Diminished IFN- $\gamma$ production may have resulted in diminished NO production. Alternatively, increased NO production may have inhibited IFN $-\gamma$ production by $T$ cells or natural killer cells, possibly by damaging these cells. Indeed, thymi of BALB/c-wt mice treated with IL-12 and IL-18 showed marked atrophy with cell apoptosis (data not shown), possibly leading to a reduced $\mathrm{T}$ cell supply from the thymus. $\mathrm{NO}$ is an important cytotoxic molecule in the defence against microorganisms, ${ }^{42}$ tumour cells, ${ }^{43}$ or other NO sensitive cells. ${ }^{44}$ Furthermore, NO and/or its oxidised forms have the capacity to induce apoptosis in murine peritoneal macrophages $^{42}$ and thymocytes ${ }^{45}$ by directly damaging DNA. ${ }^{46}$ Interestingly, NO can also serve as an antioxidant in the presence of reactive oxygen species and protect the host from the cytotoxic action of reactive oxygens. ${ }^{47}$ As noted above, we showed that IL-12 and IL-18 induced an increase in serum levels of NO (fig 3). As NO is a cytotoxic molecule that induces cell apoptosis, we suspected that NO might have a crucial role in inducing the pathological state. But iNOS KO mice injected with IL-12 and IL-18 also manifested weight loss accompanied by intestinal inflammation (figs $1 \mathrm{~B}$; fig $5 \mathrm{C}, \mathrm{F})$, which indicates that NO did not have a crucial role in inducing the pathological state.

The mechanism of induction of severe fatty liver by IL-12 and IL-18 remains unknown. As injection of a mixture of IL-12 and IL-18 failed to induce fatty degeneration in the liver of IFN- $\gamma$ KO mice (fig $6 \mathrm{D}$ ), IFN- $\gamma$ seems to play an important role. But in iNOS KO mice injected with IL-12 and IL-18, increased levels of IFN- $\gamma$ were observed (fig $2 \mathrm{~B}$ ) but there were no fatty changes in the liver (fig $6 \mathrm{E}$ ). Hence NO may have a crucial role in inducing fatty degeneration.

Sequential administration of $P$ acnes and LPS has been shown to induce severe liver injury. ${ }^{4{ }^{18}}$ But LPS up to $10 \mu \mathrm{g} / \mathrm{mouse} /$ day did 
not cause such serious manifestations or severe histological changes (data not shown). Even if there was some leakage of LPS from the gut, it was of little importance in inducing the pathological changes observed in mice injected with IL-12 and IL-18.

In summary, we demonstrated the pathological role of IL-12 and IL-18 in inducing weight loss with intestinal inflammation and fatty liver. The pathological changes in the intestine were Th1 cells and IFN- $\gamma$ dependent but TNF- $\alpha$, NO, and Fas L independent. Fatty changes in the liver were NO dependent. Further study of the control of IL-18 production may provide a clinical approach for the treatment of disorders which are Th1 dependent.

We thank Mr K Takemura and Ms. T Takada for assistance in electron microscopy. This study was supported by a Grant-in-Aid for Scientific Research and Hitech Research Center grant from the Ministry of Education, Science and Culture of Japan and by CREST (Core Research for Evolutional Science and Technology) of Japan Science and Technology Corporation (JST).

1 Mossmann TR, Coffman RL. Th 1 and Th 2 cells: different patterns of lymphokine secretion lead to different functional properties. Annu Rev Immunol 1989;7:145-73.

2 Trinchieri G. Interleukin-12: a proinflammatory cytokine with immunoregulatory functions that bridge innate resistance and antigen-specific adaptive immunity. Annu Rev Immunol 1995;13:251-76.

3 Sedar RA, Paul WE. Acquisition of lymphokine producing phenotype by $\mathrm{CD}^{+}$T cells. Annu Rev Immunol 1994;12: 635-73.

4 Okamura H, Tsutsui H, Komatsu T, et al. Cloning of a new cytokine that induces IFN- $\gamma$ production by $\mathrm{T}$ cells. Nature 1995;378:88-91.

5 Yoshimoto T, Nakanishi K, Hirose S, et al. High serum IL-6 level reflects susceptible status of the host to endotoxin and IL-1/tumor necrosis factor f Immunol 1992;148:3596-603.

6 Tsutsui H, Mizoguchi Y, Morisawa S. Importance of direct hepatocytolysis by liver macrophages in experimental hepatocytolysis by liver macrophages in experime
fulminant hepatitis. Hepatogastroenterol 1992;39:553-9.

7 Waage A, Espevik T. Interleukin 1 potentiates the lethal effect of tumor necrosis-factor $\alpha /$ cachectin in mice. $f$ Exp Med 1988;167:1987-92

8 Okusawa S, Gelfand JA, Ikejima T, et al. Interleukin linduces a shock-like state in rabbits. F Clin Invest 1988;81 $1162-72$

9 Beutler B, Cerami A. The biology of cachectin/TNF a primary mediator of the host response. Anпu Rev Immuno 1989;7:625-55

10 Ushio S, Namba M, Okura T, et al. Cloning of the cDNA for human IFN- $\gamma$-inducing factor, expression in Escherichia coli, and studies on the biologic activities of the protein. $\mathcal{F}$ Immunol 1996;156:4274

11 Okamura H, Tsutsui H, Kashiwamura S, et al. Interleukin-18 (IL-18): a novel cytokine that augments both innate and acquired immunity. Adv Immunol 1998;70: 281-312.

12 Takeda K, Tsutsui H, Yoshimoto T, et al. Defective NK cell activity and Th1 response in IL-18-deficient mice. Immunity 1998;8:383-90.

13 Matsui K, Yoshimoto T, Tsutsui H, et al. Propionibacterium acnes treatment diminishes $\mathrm{CD}^{+}{ }^{+} \mathrm{NK} 1.1^{+} \mathrm{T}$ cells but induces type $1 \mathrm{~T}$ cells in the liver by induction of IL-12 and IL-18 production from kupffer cells. F Immunol 1997;159: 97-106.

14 Kohno K, Kataoka J, Ohtsuki T, et al. IFN- $\gamma$-inducing factor (IGIF) is a costimulatory factor on the activation of Th1 but not Th2 cells and exerts its effect independantly of IL-12. F Immunol 1997;158:1541-50.

15 Yoshimoto T, Okamura H, Tagawa Y, et al. Interleukin 18 together with interleukin 12 inhibits $\operatorname{IgE}$ production by induction of interferon $\gamma$ production from activated B cells. Proc Natl Acad Sci USA 1997;94:3948-53.

16 Ahn HJ, Maruo S, Tomura M, et al. A mechanism underlying synergy between IL-12 and IFN- $\gamma$-inducing factor in synergy between IL-12 and IFN- $\gamma$-inducing factor in
enhanced production of IFN- $\gamma$. F Immunol 1997;159:2125131.

17 Yoshimoto T, Takeda K, Tanaka T, et al. IL-12 up-regulates IL-18R expression on T cells, Th1 cells and B cells: synergism with IL-18 for IFN- $\gamma$ production. $\mathcal{F}$ Immunol 1998;161:3400-7

18 Tsutsui H, Matsui K, Kawada N, et al. 1997. IL-18 accounts for both TNF- $\alpha$-and Fas ligand-mediated hepatotoxic pathways in endotoxin-induced liver injury in mice. $f$ Immunol 1997;159:3961-7.

19 Tsutsui $\mathrm{H}$, Nakanishi K, Matsui K, et al. IFN- $\gamma$-inducing factor up-regulates Fas ligand-mediated cytotoxic activity of murine natural killer cell clones. F Immunol 1996;157: 3967-73.

20 Tanaka Y, Takahashi A, Watanabe K, et al. A pivotal role of IL-12 in Th-1 dependent mouse liver injury. Int Immunol 1996;8:569-76.
21 Stenson WF. Animal models of inflammatory bowel disease. In: Targan SR, ed. Inflammatory bowel disease: from bench to bed side. Baltimore: Williams and Wilkins, 1994:180-92.

22 Powrie F, Leach M, Mauze WS, et al. Phenotypically distinct subsets of $\mathrm{CD}^{+} \mathrm{T}$ cells induce or protect from chronic intestinal inflammation in CB-17 Scid mice. Int Immunol 1993;5:1461-71.

23 Morrissey PJ, Charries K, Braddy S, et al. CD4 ${ }^{+}$Tcells that express high levels of CD45RB induce wasting disease when transferred into congenic severe combined immunodeficient mice. Disease development is prevented by cotransfer of purified CD $4^{+}$Tcells. $\mathcal{F}$ Exp Med 1993;178: 237-44.

24 Powrie F, Leach MW, Mauze S. Inhibition of Th1 responses prevents IBD in SIID mice reconstituted with CD45RB ${ }^{\text {hig }}$ $\mathrm{CD}^{+} \mathrm{T}$ cells. Immunity 1994;1:553-62.

25 Ito H, Fathman CG. CD $45 \mathrm{RB}^{\text {high }} \mathrm{CD} 4{ }^{+} \mathrm{T}$ cells from IFN- $\gamma$ knockout mice do not induce wasting disease. 7 Autoimmun 1997;10:455-9.

26 Powrie F, Carlino J, Leach MW, et al. A critical role for transforming growth factor- $\beta$ but not interleukin- 4 in the supression of $\mathrm{T}$ helper type 1-mediated colitis by CD45RB ${ }^{\text {low }} \mathrm{CD}^{+}$Tcells. F Exp Med 1996;183:2669-74.

27 Hollander GA, Simpson SJ, Mizoguchi E, et al. Severe colitis in mice with aberrant thymic selection. Immunity 1995; 3:27-38.

28 Strober W, Keelsall B, Marth T, et al. Reciprocal IFN- $\gamma$ and TGF- $\beta$ responses regulate the occurrence of mucosal inflammation. Immunol Today 1997;18:61-4.

29 Boirivant M, Fuss IJ, Chu A, et al. Oxazolone colitis: A murine model of T helper cell type 2 colitis treatable with antibodies to interleukin 4. F Exp Med 1998;188:1929-39.

30 Dieleman LA, Palmen MJ, Akol $\mathrm{H}$, et al. Chronic experimental colitis induced by dextran sulphate sodium (DSS) is characterized by Th1 and Th2 cytokines. Clin Exp mmunol 1998;114:385-91.

31 Simpson SJ, Samir S, Comiskey M, et al. T cell-mediated pathology in two models of experimental colitis depends predominantly on the interleukin 12/signal transducer and activator of transcription (Stat-4) pathway, but is not conditional on interferon $\gamma$ expression by T cells. F Exp Med 1998;187:1225-34.

32 Tagawa Y, Sekikawa K, Iwakura Y. Suppression of concanavalin A-induced hepatitis in IFN- $\gamma-/-$ mice, but not in TNF- $\alpha-/-$ mice: role for IFN- $\gamma$ in activating apoptosis of hepatocytes. F Immunol 1997;159:1418-28.

33 Kobayashi M, Fitz L, Ryan M, et al. Identification and purification of natural killer cell stimulatory factor (NKSF). $\mathcal{F}$ Exp Med 1989; 170:827-45.

34 Barbulescu K, Becker C, Schlaak JF, et al. IL-12 and IL-18 differentially regulate the transcriptional activity of the human IFN- $\gamma$ promoter in primary $\mathrm{CD} 4^{+} \mathrm{T}$ lymphocytes. Immunol 1998;60:3642-7.

35 Robinson D, Shibuya K, Mui A, et al.. IGIF does not drive Th1 development but synergizes with IL-12 for interferon- $\gamma$ production and activates IRAK and NF- $\kappa$ B. Immunity 1997;7:571-81.

36 Yoshimoto T, Tsutsui H, Tominaga K, et al IL-18, although antiallergic when administerted with IL-12 stimulates IL-4 and histamine release by basophils. Proc Natl Acad Sci USA 1999;96:13962-6.

37 Hoshino T, Wiltrout RH, Toung HA. IL-18 is a potent coinducer of IL-13 in NK and T cells: a new potential role for IL-18 in modulating the immune response. F Immunol 1999;162:5070-7.

38 Wild JS, Sigounas A, Sur N, et al. IFN- $\gamma$-inducing factor (IL-18) increases allergic sensitization, serum IgE, Th2 cytokines, and airway eosinophilia in a mouse model of allergic asthma. F Immunol 2000;164:2701-10.

39 Billiau A. Interferon- $\gamma$. Biology and role in pathogenesis. Adv Immunol 1996;62:61-130.

40 Nakane A, Minagawa T, Kohanawa $\mathrm{M}$, et al. Interactions between endogenous gamma interferon and tumor necrosis factor in host resistance against primary and secondary Listeria monocytogenes infections. Infect Immun 1989;57: 3331-7

41 Pieter J, Leenen M, Canono BP, et al. TNF- $\alpha$ and IFN- $\gamma$ stimulate a macrophage precursor cell line to kill Listeria monocytogenes in a nitric oxide-independent manner. $f$ Immunol 1994;153:5141-7.

42 Adams LB, Hibbs JB Jr, Taintor RR, et al. Microbiostatic effect of murine-activated macrophages for Toxoplasmagondii. F Immunol 1990;144:2725-9.

43 Stuehr JD, Nathan CF. A macrophage product responsible for cytostasis and respiratory inhibition in tumor target cells. F Exp Med 1989;169:1543-55.

44 Moncada SR, Palmer MJ, Higgs EA. Nitric oxide: physiology, pathophysiology, and pharmacology. Pharmacol Rev 1991;43:109-42.

45 Fehsel K, Kroncke KD, Meyer KL, et al. Nitric oxide induces apoptosis in mouse thymocytes. 7 Immunol 1995; 155:2858-65.

46 Nguyen T, Brunson D, Crepsi CL, et al. DNA damage and mutation in human cells exposed to nitric oxide in vitro. Proc Natl Acad Sci USA 1992;89:3030-4.

47 Wink DA, Cook JA, Krishna MC, et al. Nitric oxide protects against alkyl peroxide-mediated cytotoxicity: further insights into the role nitric oxide plays in oxidative stress. Arch Biochem Biophys 1995;319:402-7. 